\title{
PHYTOMINING OF GOLD FROM ELSUKARI MINE SOIL
}

EI-Kassas, H. I. ${ }^{(1)}$; Abd El-Razek, Taha. A. M. ${ }^{(1)}$ and Japer, M. H. 1) Institute of Environmental Studies and Researches, Ain Shams University Ain Shams University

\begin{abstract}
The present study aims at using phytomining technology to extract gold from ElSukari soil by Helianthus annuus L plant. This is achieved by adding three solubilizing: ammonium thiocyanate, ammonium thiosulphate and thiourea. $300 \mathrm{~kg}$ soil was divided into four treatments(three of these gold solubilizing agents) by $3 \mathrm{~kg}$ per pot and 25 pots for each treatment Harvest intervals were 15, 30 and 60 days. Then, the plant parts were subjected to analysis of the concentration of gold using AAS (Flame + graphite furnace spectrometry). The results showed that there is an increase in the absorption of gold by some plants when phytomining is applied to induce gold absorption using Helianthus annuus L. at temperatures conditions ranging from 13.6 - $29.2^{\circ} \mathrm{C}$, Abu Rawash in Giza government, and $\mathrm{pH}$ 7.7of ElSukari soil and containing $1.42 \mathrm{mg} \mathrm{kg}-1$ (ppm) of gold element. At age of 30 days, gold content in root reached up to 8.02, 4.14 and $2.8 \mathrm{ppm}$ for ammonium thiosulphate, thiourea and ammonium thiocyanate treatment respectively. Leaf gold recorded 4.48, 5.65 and $0.3 \mathrm{ppm}$ upon treatment with for ammonium thiosulphate, thiourea and ammonium thiocyanate treatment respectively.

Key words: Gold, Phytoremediation, Mine Soil.
\end{abstract}

\section{INTRODUCTION}

Phytomining is the use of plants and bacteria specialized in the absorption of gold from the soil and its accumulation within the biomass of plants or bacteria and thereafter treating biomass in different ways to produce gold. Phytomining is green technology alternative and more environmentally 
friendly and less expensive (Anderson et al., 2005 and, Gavrilesc et al., 2009).

Gold is a very precious metal and a chemical element that has the symbol

$\mathrm{Au}$ with atomic number 79 and atomic weight 197 with soft and shiny yellow color. It is used in the manufacture of jewelry and gems. Residues in nature in the form of granules inside rocks and riverbeds, or in the form of veins in the ground, and often there is gold with other metals such as copper and lead.It is also among the high density chemical elements as they reach density of $19.5 \mathrm{~g} / \mathrm{cm} 3$.

Phytomining requires the use of cyanide once only, over a timeframe of minutes, where the purpose of the chemical is to promote sufficient solubility for uptake. Solubility and availability of the metal is one of the key limiting factors for gold phytomining (Piccinin et al., 2007).

These gold solubilizing agents was recently used and reported for solubilization of heavy metals from gold bearing ores (Ebbs et al., 2010).

During phytomining the irrigation with chemical is designed to mitigate the potential for leaching of the chemical and gold out of the root zone.

Nowack et al., (2006). suggested that much discussion has been made on the environmental consequences of using the chemical EDTA during phytoextraction.

Thus, phytomining for gold solubilizing could be considered as an economically viable and environmentally sustainable technology that might operate alongside conventional technology at operating mining sites, or alone at legacy sites. 
Further research is needed at the physiological and biochemical level for optimization of the process, greater understanding of how plants absorb, translocate and metabolize gold. Identification of genes responsible for gold uptake,needs further inveatigation.

The plants used for induced hyperaccumulation do not have to be exotic species.

ElSukari mine is a huge ore located in the Nubian Desert (part of the Eastern Desert), $30 \mathrm{~km}$ from the city of Marsa Alam .

The aim of this work is to investigate the solubilizing agents behavior of gold using Helianthus sp. with the aid of some solubilizing agents i.e ammonium thiosulphate, ammonium thiocyanate and thiourea. 
J. Environ. Sci.

Institute of Environmental Studies and Research - Ain Shams University

\section{MATERIAL AND METHODS}

Soil used for plant growth: $300 \mathrm{kgm}$ grounded rock from elsukari area (Gazelle zone) were been grinding.

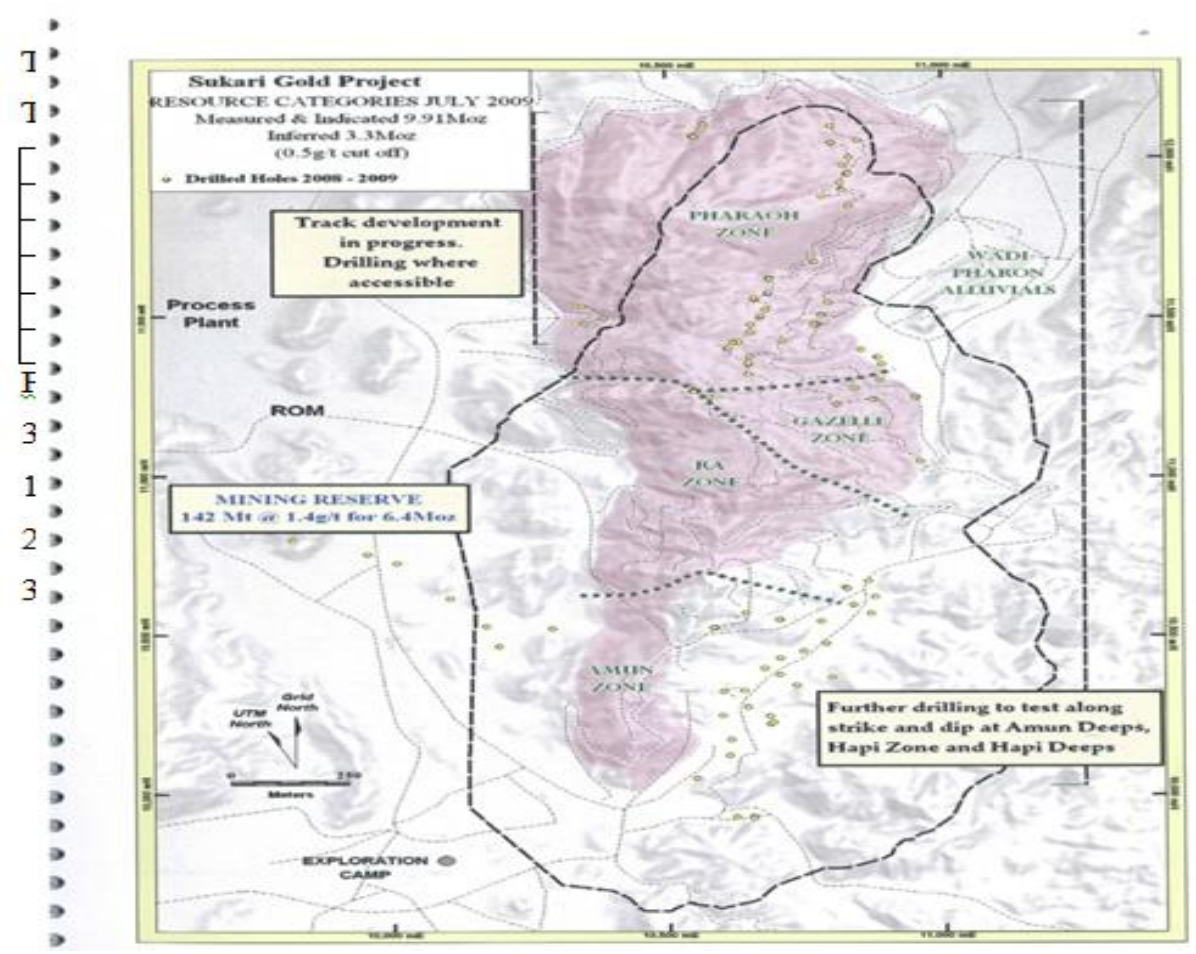

Fig.(1): Location of El Sukari mine (Resource Categories july, 2009).

The Chemical and physical characteristics of this soil are shown in table 1.

Table(1): Physico-chemical characteristics of the El Sukari soil.

\begin{tabular}{|c|c|c|}
\hline $\mathbf{A u}$ & $\mathbf{1 . 4 2}$ & ppm \\
\hline $\mathrm{pH}$ & 7.70 & - \\
\hline $\mathrm{CaO}$ & 4.1 & $\%$ \\
\hline Organic matter & 1.0 & $\%$ \\
\hline $\mathrm{CaCo} 3$ & 6.45 & $\%$ \\
\hline L.O.i & 3.52 & $\%$ \\
\hline
\end{tabular}


Field trials for gold phytomining. $300 \mathrm{~kg}$ soil was divided to four treatment.

1 The first treatment with Ammonium thiocyanate from No. 1-26

2 The second treatment with Ammonium thiosulphate from No. 27-50

3 Third treatment with Thiourea from No. 51-74

Table(1-a): Some physical and chemical characteristics of the soil before planting.

\begin{tabular}{|c|c|c|c|c|c|c|c|c|c|}
\hline \multirow[t]{2}{*}{ pH } & \multirow{2}{*}{$\begin{array}{c}\text { EC } \\
\text { dS /m- } \\
\text { 1)( }\end{array}$} & \multirow[t]{2}{*}{$\begin{array}{c}\mathrm{CaCO3} \\
\%\end{array}$} & \multirow[t]{2}{*}{$\underset{\%}{\mathrm{CaO}}$} & \multirow{2}{*}{$\begin{array}{c}\text { L.O.I } \\
\% \\
\%\end{array}$} & \multirow[t]{2}{*}{$\underset{\%}{\text { O.M }}$} & \multicolumn{3}{|c|}{$\begin{array}{c}\text { Particle size } \\
\text { distribution \% }\end{array}$} & \multirow[t]{2}{*}{$\begin{array}{c}\text { Textural } \\
\text { class }\end{array}$} \\
\hline & & & & & & Sand & Silt & Clay & \\
\hline 7.7 & 0.97 & 645 & 4.1 & 3.52 & 1.0 & 76.8 & 8 & 15.2 & $\begin{array}{c}\text { Loamy } \\
\text { sand }\end{array}$ \\
\hline
\end{tabular}

*L.O.I = Limiting Oxygen Index.*

Table (1-b): Au in soil (mg Kg -1)

\begin{tabular}{|c|c|}
\hline Element & concentration \\
\hline \hline $\mathrm{Au}$ & 1.42 \\
\hline
\end{tabular}

Table (2): The values of $\mathrm{pH}$ and EC in soil after irrigation .

\begin{tabular}{|c|c|c|}
\hline Treatment & pH & $\begin{array}{c}\text { EC } \\
\mathbf{d S} / \mathbf{m}-\mathbf{1})(\end{array}$ \\
\hline \hline Ammonium thiocyanate & 7.4 & 0.4 \\
\hline Ammonium thiosulphate & 7.35 & 0.94 \\
\hline Thiourea & 7.39 & 0.66 \\
\hline
\end{tabular}


J. Environ. Sci.

Institute of Environmental Studies and Research - Ain Shams University

Table (3): Effect of dryness in plant at age 15, 30 and 60 days.

\begin{tabular}{|c|c|c|c|c|c|c|c|c|c|c|}
\hline \multirow{2}{*}{$\begin{array}{c}\text { Part } \\
\text { of } \\
\text { plants }\end{array}$} & \multirow{2}{*}{$\begin{array}{c}\text { Periods } \\
\text { (days) }\end{array}$} & \multicolumn{3}{|c|}{$\begin{array}{l}\text { Ammonium } \\
\text { thiocyanate }\end{array}$} & \multicolumn{3}{|c|}{$\begin{array}{l}\text { Ammonium } \\
\text { thiosulphate }\end{array}$} & \multicolumn{3}{|c|}{ Thiourea } \\
\hline & & Fresh & Dry & $\begin{array}{c}\text { Dec. } \\
\%\end{array}$ & Fresh & Dry & $\begin{array}{c}\text { Dec. } \\
\%\end{array}$ & Fresh & Dry & $\begin{array}{c}\text { Dec. } \\
\%\end{array}$ \\
\hline$\overline{\text { Root }}$ & \multirow{3}{*}{5 days } & 2.27 & 0.3 & 10.94 & 1.18 & 0.24 & 19.15 & 1.95 & 0.46 & 21.63 \\
\hline Stem & & 6.03 & 3.0 & 43.72 & 10.38 & 5.03 & 38.07 & 8.69 & 3.74 & 34.34 \\
\hline Leaves & & 4.27 & 1.36 & 27.58 & 6.42 & 3.05 & 41.08 & 5.46 & 2.08 & 32.63 \\
\hline Root & \multirow{3}{*}{30 days } & 0.437 & 0.286 & 65.00 & 0.773 & 0.486 & 62.09 & 1.394 & 1.149 & 81.03 \\
\hline Stem & & 2.511 & 1.589 & 60.77 & 2.453 & 1.055 & 40.55 & 3.580 & 2.941 & 78.57 \\
\hline Leaves & & 2.875 & 1.182 & 38.23 & 3.907 & 1.939 & 45.72 & 4.715 & 3.579 & 71.19 \\
\hline Root & \multirow{3}{*}{60 days } & 1.79 & 0.66 & 35.08 & 1.72 & 0.60 & 33.16 & 3.75 & 1.151 & 26.94 \\
\hline Stem & & \begin{tabular}{|l|}
4.17 \\
\end{tabular} & 0.67 & 11.89 & 2.55 & 0.63 & 22.15 & 7.7 & 1.11 & 6.71 \\
\hline Leaves & & 5.49 & 1.24 & 17.09 & 5.33 & 1.07 & 14.74 & 9.96 & 1.95 & 9.61 \\
\hline
\end{tabular}

*Dec. $=$ Decrease $\%=($ fresh weight - dry weight $) /$ fresh weight $\mathrm{x} 100$

Field trials for gold phytomining: $300 \mathrm{~kg}$ soil was divided to four treatments as follows:

1 -The first treatment : ammonium thiocyanate from No. 1-26

2 -The second treatment: ammonium thiosuphate from No. 27-50

3-Third treatment :Thiourea from No. 51-74

4-Four treatment : Control from No. 75-100

plants were harvested at intervals of 15,30 and 60 days The pots were fertilized with chemical fertilizers $(\mathrm{N}-\mathrm{P}-\mathrm{K})$ at a rate of 1 gram hybrid SB / liter of water. The plants were cultivated for 60 days in a greenhouse at temperature range of $14-29$ o $\mathrm{C}$. At the end of the 60 days growth period, each pot was assigned one of four treatments.

Treatment application rates in moles of chemical per $\mathrm{kg}$ of soil and grams of chemical per $\mathrm{kg}$ of soil are presented in Table 4. 
Table(4): Treatment rates applied to Helianthus annuus L growing in El Sukari Soil.

\begin{tabular}{|c|c|c|}
\hline Chemical & Treatment rate (mol kg -1) & Treatment rate $\mathbf{( g ~ k g ~ - 1 )}$ \\
\hline \hline $\mathrm{NH} 4 \mathrm{SCN}$ & 0.0140 & 1.24 \\
\hline$(\mathrm{NH} 4) 2 \mathrm{~S} 2 \mathrm{O} 3$ & 0.0312 & 2.00 \\
\hline $\mathrm{SC}(\mathrm{NH}) 2$ & 0.0002 & 0.03 \\
\hline
\end{tabular}

Note: all treatments were applied to pots as $150 \mathrm{~mL}$ of solution.

A dose of $2 \mathrm{~g} \mathrm{~kg} \mathrm{-1} \mathrm{of} \mathrm{(NH4)2S2O3} \mathrm{was} \mathrm{reported} \mathrm{in} \mathrm{a} \mathrm{greenhouse} \mathrm{study} \mathrm{(}$ Msuya et al., 2000). Finally, the dose of SC (NH2)2 used in this study is equivalent to double the dose used and reported by Rodriguez et al. (2006).

After harvesting, plant samples were dried at 70o $\mathrm{C}$ par $12 \mathrm{~h}$ and then milled.

Chemical Analysis: Gold analysis was conducted in the Ministry of Petroleum and Mineral Resources (the central laboratories sector) as follows. The following steps were performed on each of the root, stem or leaves 1 -The root was dried in the dryer for 12 hours at a temperature of $70^{\circ} \mathrm{C}$.

2 - The root was weighted after drying

3 - The sample was dissolved in $100 \mathrm{ml}$ (aqua ragia) mixture of nitric acid and hydrochloric acid (3:1).

4 - The sample was left on the heater for 15 minutes until brown fumes

5 - The sample was transferred in $100 \mathrm{ml}$ Flask then shaked well.

6 - The sample was measured by the atomic absorption device Flame Atomic Absorption Spectrophotometer using this device to perform quantitative analysis of element percentages or as parts of a million ( $\mathrm{p} \mathrm{p} \mathrm{m)} \mathrm{for} \mathrm{gold}$

7 - A standard solutions curve was applied according to the following law : ( $\gamma \times \mathrm{V}) / \mathrm{W}$ 
Where V = volume of Flask

Where $\gamma=$ read the device

Where $\mathrm{W}=$ sample weight

Johnr et al.(1999).

\section{RESULTS AND DISCUSSION}

Pots experiment: The gold concentration in Helianthus annuusL harvested plant i.e. the leaves, stems, and roots of control and chemically treated soils are presented in Tables $(5,6,7$, and 8$)$.

Table(5): Gold concentration (ppm ) in H.annusL plants after 15,30 and 60 days with Ammonium thiocyanate treatment.

\begin{tabular}{|c|c|c|c|}
\hline \multirow{2}{*}{ Plant growth period } & \multicolumn{3}{|c|}{ Ammonium thiocyanate } \\
\cline { 2 - 4 } & Root & Stem & Leaves \\
\hline \hline 15 day & 0.01 & 0.01 & 0.006 \\
\hline 30 day & 2.8 & 0.3 & 5.77 \\
\hline 60 day & N.D & N.D & N.D \\
\hline
\end{tabular}

$*$ N.D $=$ Not detected

Table(6): Gold concentration (ppm) in H.annusL plants after 15, 30 and 60 days with Ammonium thiosulphate treatment

\begin{tabular}{|c|c|c|c|}
\hline \multirow{2}{*}{ Plant growth period } & \multicolumn{3}{|c|}{ Ammonium thiosulphate } \\
\cline { 2 - 4 } & Root & Stem & Leaves \\
\hline \hline 15 day & 0.01 & 0.006 & 0.006 \\
\hline 30 day & 8.02 & 4.48 & 5.92 \\
\hline 60 day & N.D & N.D & N.D \\
\hline
\end{tabular}

$*$ N.D $=$ Not detected 
Table(7): Gold concentration (ppm) in H.annusL plants after 15 ,30 and 60 days with thiourea treatment.

\begin{tabular}{|c|c|c|c|}
\hline \multirow{2}{*}{ Plant growth period } & \multicolumn{3}{|c|}{ Thiourea } \\
\cline { 2 - 4 } & Root & Stem & Leaves \\
\hline \hline 15 day & N.D & 0.008 & 0.01 \\
\hline 30 day & 4.14 & 2.65 & 3.27 \\
\hline 60 day & N.D & N.D & N.D \\
\hline
\end{tabular}

$*$ N.D $=$ Not detected

Table(8): Gold concentration in soil after 30 and 60 days.

\begin{tabular}{|c|c|}
\hline Detection time & Gold concentration (ppm) \\
\hline \hline 30 day & 1 \\
\hline 60 day & 0.54 \\
\hline
\end{tabular}

Ammonium thiosulphate increased the gold concentration in plant parts, however the results were very variable.

This may reflect a non homogenous distribution of gold in the soil, and uneven distribution of the soluble gold Ammonium thiosulphate throughout the root zone of the plants. The maximum gold concentration recorded was $8.2 \mathrm{mg} / \mathrm{kg}$ for the roots, $4.48 \mathrm{mg} \mathrm{kg}-1$ for stem, and $5.92 \mathrm{mg} \mathrm{kg}-1$ for leaves after 30 days.

The maximum gold values recorded for this pots experiment were slightly lower than those recorded by Anderson et al. (2005), during their field experiment in Brazil where the plant species Brassica junica and Zea mays were tested for their ability to absorb mobilized gold after cyanide and thiocyanate treatment. Brassica juncea showed the best ability to concentrate gold giving an average of $39 \mathrm{mg} \mathrm{kg}-1$ after sodium cyanide treatment. 
The amount of gold adsorption, qt (mg Au/g) was computed according to the following equation: $\mathrm{qt}=\frac{(\mathrm{Ci}-\mathrm{Ct}) \mathrm{W}}{\mathrm{W}}$

Where $\mathrm{Ci}$ and $\mathrm{Ct}$ are the concentrations of gold in solution $(\mathrm{mg} / \mathrm{L})$ at initial time and at time $\mathrm{t}$, respectively; $\mathrm{V}$, the volume of solution $(\mathrm{mL})$ and $\mathrm{W}$, the dosage of sorbent used (mg).

The influence of microbial activity on the gold solubilization depends on the ability of the microorganisms to promote gold oxidation and to excrete ligands capable of stabilizing the resulting gold ions by forming complexes or colloids (Reith and Mo phail., 2007).

While half the helianthus annuus L plnats were dead a 40 days after treatment: it is important to note that dead plants, as live plants provided no biomass is lost. In the case of gold phytomining this may even be advantageous as it would be known that maximum gold uptake had occurred and would eliminate the need to dry the tissue prior to recovery of the gold.

The highest average and maximum concentration was achieved using thiosulphate, followed by thiocyanate. The average gold concentration of the plants treated with cyanide was the same as for the control. This is due to the relevant gold complexes being stable under different geochemical conditions (Anderson,etal, 2005).

Thiocyanate, however, was the first chemical used to induce gold uptake in plants. But in later years, researchers have focused on cyanide, as this chemical is actually less toxic to plants.

Gold phytomining can be improved by the discovery of fast growing plants with high biomass and ability to accumulate high concentration of gold 
in the harvestable parts. The cheap methodology of recovery of gold from plant biomass is also an area of research.

The true potential of the phytomining is yet to be established, it requires integrated multidisciplinary research efforts that combine plant biology, genetic engineering, soil chemistry and soil microbiology, as well as agricultural and environmental engineering. Phytomining of gold is a 'green' approach to the environmentally sensitive and energy intensive practice of mining, involving the use of selective plants to extract valuable metals from both solid and liquid substrates.

It is a viable alternative or supplementary to conventional mining methods of low grade gold ore bodies' soil.

Typical feedstocks for a phytomine are metalliferous sites with low metal content that cannot be economically mined using conventional technology or sites with high metal content that possess significant risk to the environment due to anthropogenic activities.

The process improves the quality of the soil for postmining applications over the duration of phytomining. Removal of metals and the increased fertility of the land that results from improved management practices are the two key benefits of phytomining.

\section{REFERENCES}

Anderson, C, Moreno, F, and Meech, J, (2005): A field demonstration of gold phytoextraction technology. Minerals Engineering 18: 385-392.

Ebbs, S.D., Kolev, S.D., Piccinin, R.C.R.,Woodrow, I.E., and BakerA.J.M., (2010): Solubilization of heavy metals from gold ore by Adjuvants used during gold phytomining. Minerals Engineering 23 (10):819-822. 
Haverkamp, R.G.,Marshall,A.T.and vanAgterveld,D.,(2007):Pick your carats:nano particles of gold -silver -copper alloy produced in vivo. Journal of Nano particle Research 9: 697-700.

GavrilescM, L.V. Paveland I. Cretescu(2009): Characterization and remediation Of soils contaminated with uranium. JHazard Mater, 163: $475-510$.

John R . Clark and James R . Yeager.(1999):Gold Analysis-Fire Assaying and Alternative Methode. Mining Geot.,7(2):155-160.

Msuya, F.A., Brooks,R.R.,Anderson,C.W.N.,(2000):Chemically induced uptake Of gold by root crops : its significance for phytomining. Gold Bulletin 33 (4) : 134-137.

Nowack B., and Schulin R., Robinson B .H. (2006) : Critical assessment of chelant enhanced metal phytoextraction. Environ. Sci. Technol., 40: $5225-5232$

Piccinin, R.C.R., Stephen, D.E., Suzie, M.R.,Kolev, S.D.,Woodrow, I.E.and Baker, A.J.M.,( 2007). A screen of some native Australian flora and exotic agricultural species for their potential application in cyanide induced phytoextraction of gold.Minerals Engineering 20:1327-1330.

Reith F, and McPhail DC. (2007). Microbial influences on solubilisation and mobility of gold and arsenic in regolith samples from two gold mines in semi-arid and tropical Australia. Geochim Cosmochim Acta 71: 1183-1196.

Rodriguez, E. ,Sanchez -Salcido, B., Peralta -Videa, J.R ., Romero, J .CruzJimenez, G., Gardea-Torresdey, J.L., (2006) : Phytomininggold : Soil trials.ln : 231 st American Chemical Society Nationl Meeting, Division of Environmental chemistry, Atlanta GA, pp.384-389.

Rodriguez, E., Gardea-Torresdey, J.L., Parsons, J.G., Peralta -Videa, J. R., Meitzner, G.,and Cruz-Jimenez, G. (2005): Use of ICP and XAS to determine the enhancement of gold phytoextraction by Chilopsis linearis using thiocyanate as a complexing agent. Analytical and Bioanalytical Chemistry 382 (2): 347-352. 


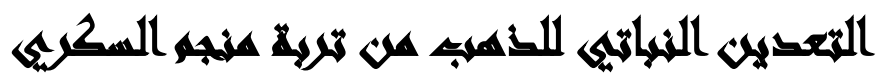

[7]

هثام إبراهيم القصاص(') - طه عبد العظيم محمد عبد الرازق(') - محمد حسن جابر

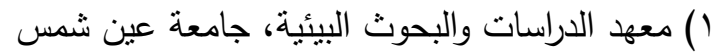

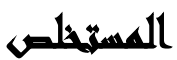

تهدف هذه الدراسة إلى استخدام تقنية التعدين النباتي في استخلاص الذهب من نربة منجم إناف

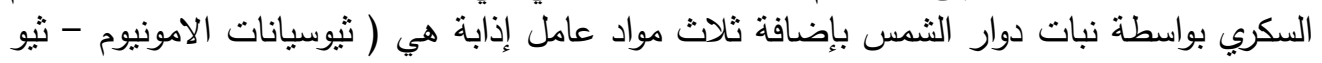

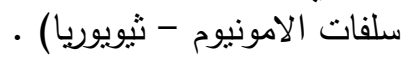

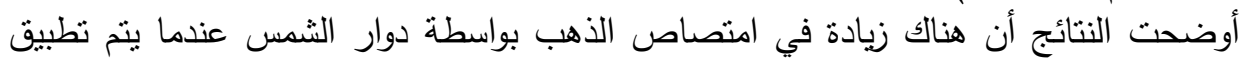

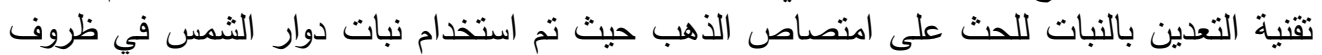

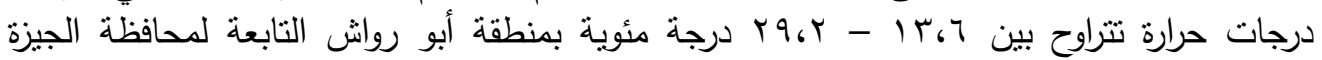

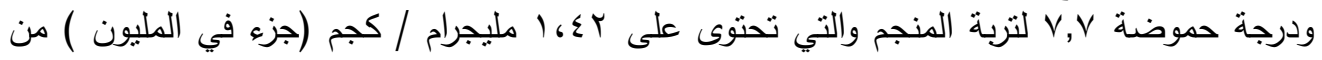

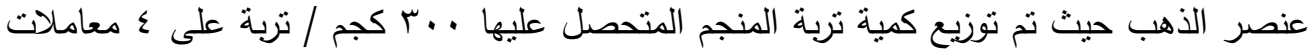

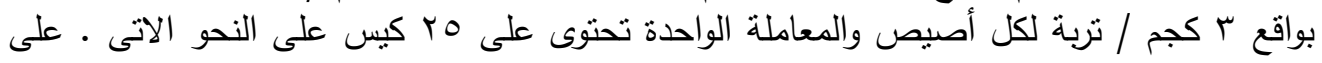

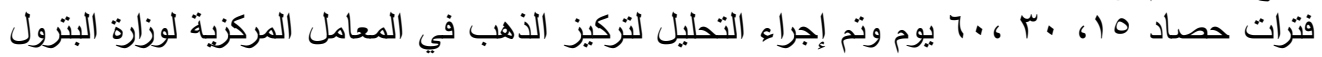

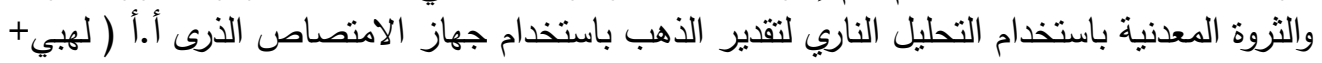

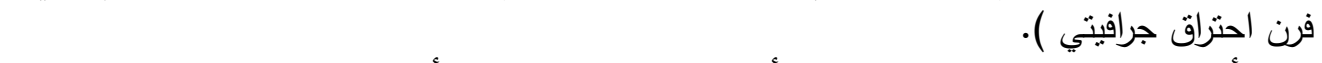
أظهرت النتائج في معظم الحالات أن تركيزات الذهب كان كانت أعلى في الجذور مما كانت عليه

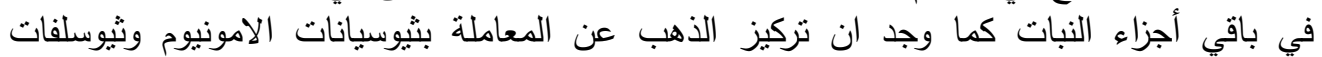

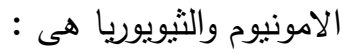

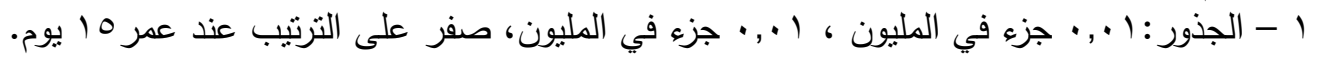

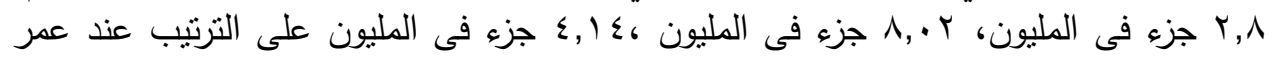

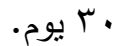

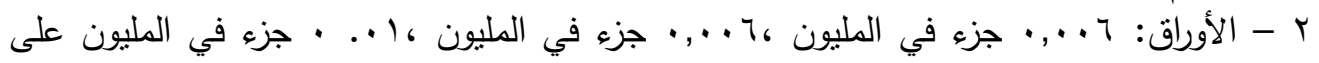

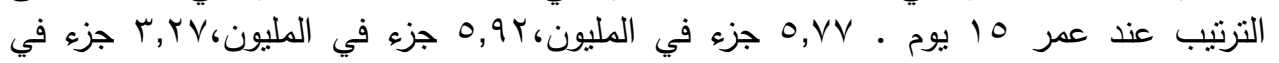

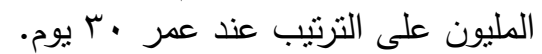

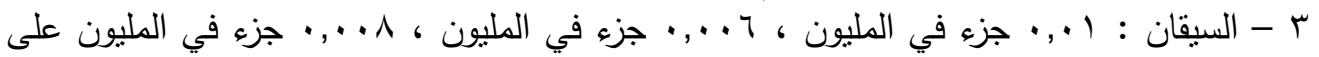

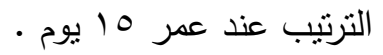

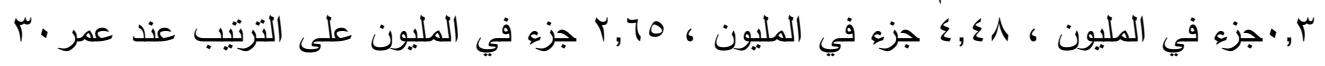

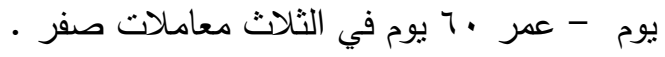

